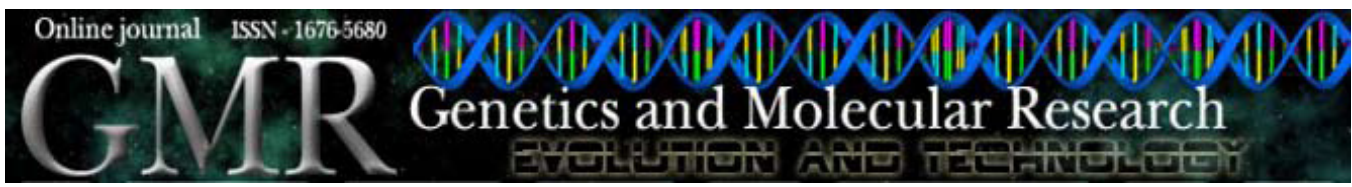

$\underline{\text { Review }}$

\title{
Leukemia/lymphoma-associated gene fusions in normal individuals
}

\author{
M.S. Brassesco \\ Departamento de Pediatria e Puericultura, \\ Faculdade de Medicina de Ribeirão Preto, USP, Ribeirão Preto, SP, Brasil \\ Corresponding author: M.S. Brassesco \\ E-mail: marsol@rge.fmrp.usp.br, solbrassesco@hotmail.com
}

Genet. Mol. Res. 7 (3): $782-790$ (2008)

Received June 12, 2008

Accepted June 30, 2008

Published September 2, 2008

\begin{abstract}
Hematopoietic neoplasias are characterized by recurrent chromosomal aberrations that result in the formation of gene fusions and the subsequent expression of chimeric proteins with unique properties. However, in recent years, different lymphoma/leukemia-associated rearrangements, such as BCR/ABL, IGH/BCL2, ETV6/RUNX1 and MLL duplications, have been detected in healthy individuals. The presence of these rearrangements indicates that such translocations can be generated in normal hematopoietic cells without apparent oncogenic consequences. This article reviews and discusses the data available in the literature.
\end{abstract}

Key words: Gene fusions; Genomic instability; Leukemia; Lymphoma; Healthy individuals 


\section{INTRODUCTION}

Several lines of evidence indicate that tumorigenesis is a multistep process with accumulative genetic alterations that drive the progressive transformation of normal human cells into highly malignant derivatives (Hanahan and Weinberg, 2000).

Generally, lymphoid malignancies are characterized by recurrent chromosomal aberrations that lead to the formation of gene fusions and the subsequent expression of chimeric proteins with unique properties (Greaves, 1999). These genetic alterations are important for leukemogenesis and define in most cases subsets of disease, becoming themselves important for prognostic and therapeutic purposes (Coustan-Smith et al., 2000).

Mainly, there are two types of fusion genes. The first one is unique to the lymphoid system, where putative oncogenes are mobilized into the vicinity of the genes encoding immunoglobulin $(I G H)$ or T-cell receptor $(T C R)$ molecules. The other, is actual chimerism, resulting in functional alterations such as the constitutive activation of kinases or altered transcriptional regulation (Greaves, 1999). The precise molecular mechanisms leading to chromosomal translocations remain largely unknown. In cases where $I G H$ or TCR loci are involved, there is compelling evidence that the translocation is caused by mistakes in normal V(D)J recombinase activity, as evidenced by the presence of cryptic heptamer/nonamer sequences, the addition of nontemplated nucleotides at breakpoints, and exonucleolytic deletion of germline nucleotides at these breakpoint junctions (Ferguson and Alt, 2001; Vega and Medeiros, 2003). In other translocations, homologous recombination between Alu repeats has been implicated as in the case of partial tandem duplications of $M L L$ (Strissel et al., 1998; Strout et al., 1998; Whitman et al., 2001). Moreover, a number of other putative recombinogenic sequences have been described at breakpoints, such as topoisomerase II consensus sites and scaffold attachment regions, among others (Broeker et al., 1996; Strissel et al., 2000; Hensel et al., 2001; Strick et al., 2006), leading some investigators to speculate that such regions of the genome could be predisposed to chromosomal rearrangements.

According to Greaves (1999), independent of the mechanism underlying the formation of fusion genes, the cellular context of the molecular aberrations is critical for their possible impact. Statistical models and studies with transgenic animals indicate that leukemia development, as well as the development of solid tumors, is a multistage process that needs multiple cooperative mutations. Thus, it is plausible that different mutations, typically found in patients with leukemia or lymphoma, could arise in normal individuals (Hunger and Cleary, 1998).

Accordingly, chromosomal aberrations thought to be exclusively associated with leukemias and lymphomas have been detected in normal individuals, indicating that such translocations can be generated without apparent oncogenic consequences. The presence of tumor-associated fusion genes in healthy donors has been described for $\mathrm{t}(14 ; 18)$ IGH/BCL2 (characteristic of nonHodgkin lymphomas), with variable frequencies (16.2 to 55\%) among populations with a tendency of increasing with age (Liu et al., 1994; Yasukawa et al., 2001; Summers et al., 2001). This rearrangement has also been described in $43 \%$ of blood samples from patients with non-proliferative malignancies (Rauzy et al., 1998). Similarly, t $(9 ; 22) B C R / A B L$ was primarily detected in peripheral lymphocytes from adults and children by Biernaux et al. (1995). Afterwards, Bose et al. (1998) confirmed these data demonstrating p190 and p210 transcripts in 4 of 11 and 11 of 16 individuals, respectively. Other markers have also been detected at low frequencies in normal populations, such as ETV6/RUNX1 (Eguchi-Ishimae et al., 2001; Brassesco et al., 2004), t(11;14) 
(p13;q11) LMO2/TCR and $\mathrm{t}(7 ; 14)(\mathrm{q} 34 ; \mathrm{q} 11)$ TCR/TAL2 (Marculescu et al., 2002) and $\mathrm{t}(15 ; 17)$ $P M L / R A R A$, characteristic of promyelocytic leukemia (Quina et al., 2000). Regarding the $M L L$ aberrations, several studies have demonstrated the presence of in tandem partial duplications in almost $100 \%$ of bone marrow and peripheral blood samples from healthy donors (Schnittger et al., 1998; Bäsecke et al., 2002, 2006). MLL-translocations in normal individuals were first described by Uckum et al. (1998). In this study, rearrangements involving $M L L$ and the transcription factor $A F 4$, which results from $\mathrm{t}(4 ; 11)(\mathrm{q} 21 ; \mathrm{q} 23)$, were identified by nested-polymerase chain reaction in bone marrow samples from normal children and fetuses as well as in fetal liver samples. Subsequent studies failed to detect any transcription of such rearrangements (Kim-Rouille et al., 1999; Trka et al., 1999). However, in 2006, Brassesco demonstrated that the outstanding $49 \%$ of healthy individuals had $M L L$ rearrangements at the DNA level detected by inverse-polymerase chain reaction. These aberrations were also confirmed by fluorescence in situ hybridization showing frequencies varying between zero and 0.3 events/100 cells. Sequence analysis of individual amplimers confirmed that these rearrangements were unique and specific for $M L L$ translocations, providing evidence that these rearrangements are not restricted to malignant cells and that they may also be present in a subset of normal hematopoietic cells.

Altogether, these findings indicate that such translocations do not define per se clinically apparent diseases, but rather, malignant progression seems to depend on additional factors such as the occurrence of oncogenic secondary alterations. The clearest example concerning the necessity of secondary events is given by leukemias with the ETV6/ $R U N X 1$ fusion gene. In general, $\mathrm{t}(12 ; 21)$-positive patients show frequent deletion of the normal ETV6 gene, suggesting that the gene fusion is an initial event conferring predisposition to leukemia followed by the deletion of the gene or genes at $12 \mathrm{p}$ as a promoter event (Busson-le Coniat et al., 1999; Kempski and Sturt, 2000). Moreover, studies with ETV6/ $R U N X 1$ knock-in mice also showed that the expression of this hybrid gene is not sufficient for the in vivo induction of ALL (Andreasson et al., 2001). In the case of $M L L$, the tumorigenic capacity of translocation products seems to depend on the fusion partners. The direct participation of the $M L L / E N L$ gene in immortalization and transformation of myeloid progenitors has been demonstrated (Lavau et al., 1997; Forster et al., 2003). Contrarily, despite the cell proliferation in $M L L / A F 9$ knock-in mice, the delayed appearance of tumors suggests that secondary mutations are needed for malignancy (Dobson et al., 1999).

Actually, it is widely accepted that leukemia-associated gene fusions occur before birth. In twins with concordant ETV6/RUNX1-positive leukemia, the development of ALL has been found to occur at different times, and the postnatal latency can be variable and occasionally protracted (Wiemels et al., 1999a). For twins with concordant leukemias and $M L L$ aberrations, the concordance rate is higher, reaching almost 100\% (Greaves, 2002), and retrospective studies in neonatal blood spots have demonstrated the clonality of the rearrangements (Gale et al., 1997).

According to Greaves and Wiemels (2003), the Knudson model, in addition to the twin concordance data, indicates that for every child with a particular translocation-positive leukemia, there has to be a greater number of healthy individuals that harbor the same translocation in a silent pre-leukemic clone.

Studies of neonatal heel-stick (Guthrie) cards and stored umbilical cord blood samples showed that the frequencies of ETV6/RUNXI and RUNX1/ETO, for example, are 100 times higher in newborns than the frequency of pediatric leukemia patients with these translocations (Mori et al., 2002). Clearly, the majority of these children do not go on to develop clinical leu- 
kemia. Therefore, these rearrangements could arise in a high proportion of developing fetuses, but without the production of functional chimeric proteins; alternatively, they could originate in an inappropriate cellular context (Kim-Rouille et al., 1999). In order to produce a leukemic phenotype, these rearrangements should fulfill two conditions: 1) the structure of the gene fusion must allow the production of a functional protein and 2) the translocation must occur in early precursors with self-renewal capacity (Bose et al., 1998). Therefore, it is possible that the gene fusions in normal individuals arise in already differentiated cells or in mature precursors, which may be eliminated by normal mechanisms of cell differentiation.

It has been proposed that fusion genes could arise at initial stages of fetal development, but that the cell population could decrease (if neutral) by occasion of differentiation commitment (Nakamura, 2005). On the other hand, several studies have demonstrated the presentation of fusion gene-derived peptides by the major histocompatibility complex (Bocchia et al., 1996; Yotnda et al., 1998a,b; Pinilla-Ibarz et al., 2000), suggesting the ability of the immune system to recognize and eliminate cells that express the rearrangement.

The biological evidence that leukemias in newborns originate in utero, in addition to the involvement of epipodophylotoxins in the origin of anomalies involving the $M L L$ gene in therapy-related leukemias, have led to the hypothesis that maternal exposure to topoisomerase II inhibitors during pregnancy could be associated with the development of leukemia (Ross, 2000). According to Wiemels et al. (1999b), the exposure of mothers and fetuses to substances that interact with topoisomerase II present in the diet, medicines and environment can be orders of magnitude lower in terms of dose level, compared to drugs used in chemotherapy. However, in some cases, these compounds are as biologically active as the topoisomerase II inhibitors used in cancer treatment. It is well known that synthetic and natural flavonoids bind to topoisomerase II and form the cleavable complex, in spite of being paradoxically anticarcinogenic in some cases (Greaves, 1997). Strick et al. (2000) demonstrated that natural flavonols such as quercetin and fisetin induce the same level of breaks at 11q23 as does etoposide, while luteolin and genistein are 2-fold less effective than this drug, and in some cases, their combination showed cumulative effects for the induction of $M L L$ cleavage.

The most abundant natural sources of topoisomerase inhibitors are present in the diet, principally fruits, vegetables and grains, which are rich in isoflavonoids. The anti-oxidant effect of these substances has been widely demonstrated (Prior, 2003). Nonetheless, epidemiological studies have shown that a high ingestion of isoflavonoids does not predict a reduced risk for all cancer types (Hertog et al., 1994). In Asian countries, for example, the ingestion of isoflavonoids reaches, in some cases, $28 \mathrm{mg}$ daily (Fukutabe et al., 1996; Nakamura et al., 2000). The plasma concentration after ingestion of these substances is relatively high (Franke et al., 1998; Watanabe et al., 1998) and can persist for 2 days, suggesting that by repeated inclusion of certain foods in the diet, these substances could accumulate in plasma (Hollman et al., 1997; De Vries et al., 1998).

Epidemiological studies have also shown significant associations between infant leukemias and maternal exposure to different chemicals (Shu et al., 1996, 1999; Schüz et al., 2000; Ma et al., 2002). In the specific case of infant leukemia with $M L L$ gene fusions, a casecontrol study demonstrated significant differences for ingestion of herbal medicines, drugs such as dypirone, and insecticides (Alexander et al., 2001).

Thus, it is possible that leukemia or lymphoma-associated translocations in normal individuals could emerge as a result of exposure to genotoxic agents. It has been demon- 
strated that specific breaks involving the $M L L$ and $A M L 1$ genes can be induced in vitro by different stress or apoptotic stimuli such as serum starvation, or treatment with cytosine arabinoside (Stanulla et al., 1997; Betti et al., 2003; Vaughan et al., 2005). In the same way, specific double-strand breaks at the ETV6 intron 5 are induced after treatment with etoposide, salicilic acid, or serum starvation in immature B lymphocytes, with the subsequent formation of ETV6/RUNX1 fusions (Eguchi-Ishimae et al., 2001).

Concerning therapy-related leukemias, other than $M L L$ aberrations, several gene fusions have been demonstrated in patients, such as $\mathrm{t}(9 ; 22)$ (Hattori et al., 1995), $\mathrm{t}(3 ; 21)$ (Hiebert et al., 1996), and translocations that involve RUNX1 (Rowley, 1999) as balanced translocations with $E T O$ and $E V I I$ (Loh et al., 1998) and also t(14;21), t(17;21), t(1;21), t(15;21), and $\mathrm{t}(3 ; 21)$ (Roulston et al., 1998). Furthermore, aberrations at 11q23 have been found during treatment for a primary cancer, as in the case of $\mathrm{t}(11 ; 17) M L L / G A S P$ (Megonigal et al., 2000). These observations demonstrate the susceptibility of these genes to damage (Seeger et al., 1998).

Furthermore, it has been suggested that interindividual variation in drug metabolism by distinct phase I and phase II detoxifying enzymes or defective DNA repair could play an important role in response to low doses of topoisomerase II inhibitors and other drugs. Wiemels et al. (1999b) demonstrated that patients with $A F 4 / M L L$ fusions show frequencies of $N Q 01(\mathrm{NAD}(\mathrm{P}) \mathrm{H}$ : quinone oxido-reductase) low-activity alleles that are 2.5 times lower than in the normal population. CYP3A4 (which catalyzes epipodophylotoxins to form catechol metabolites) polymorphisms have also been associated with an increased risk of leukemia (Felix et al., 1998). Also, it has been suggested that polymorphisms in genes involved in homologous recombination repair (RAD51 and XRCC3) interact to increase the risk of developing acute myeloid leukemia (Seedhouse et al., 2004).

Altogether, the evidence in the literature suggests that exposure to certain substances and their metabolism can be involved in the origin of gene fusions. It has been demonstrated that hybrid genes that are present at low frequencies in peripheral blood of normal individuals appear to be higher in exposed populations, such as the $T R G V / B J$ hybrid gene in agricultural workers exposed to pesticides (Lipkowitz et al., 1992) and $t(14 ; 18)$ in smokers (Bell et al., 1995). Higher frequencies of several leukemia-associated translocations have also been demonstrated in patients treated for non-Hodgkin lymphoma, such as RUNX1/RUNX1T1, PMLRARA, CBFB-MYH11, MLL-MLLT1, BCR-ABL1 (Bäseke et al., 2006), BCR/ABL and IGH/MYC (Camparoto, 2005). Higher frequencies of $B C R / A B L, T R G V / B J$ have also been demonstrated in peripheral blood from patients treated for acute lymphoblastic leukemia (Camparoto, 2005), as well as ETV6/RUNX1 (Brassesco et al., 2004) and MLL fusion genes (Brassesco, 2006).

Interestingly, it has been postulated that tumor-associated translocations in peripheral lymphocytes could be transitory, since consecutive blood samples are not always positive for gene fusions as demonstrated for the $B C R / A B L$ hybrid gene (Biernaux et al., 1995) and for other rearrangements in treated patients (Bäsecke et al., 2006). Other authors suggested that such rearrangements could be expressed in hematopoietic cells that have entered the apoptotic pathway and that might have already lost their significance (Bose et al., 1998), being irrelevant in mature cells.

In this context, it is possible that gene fusions in peripheral blood lymphocytes are associated with previous exposures to diverse endogenous and exogenous sources. Since lymphocytes are circulating cells, they can be considered more vulnerable to chemical or physical agents when compared to other cell types (Tucker and Preston, 1996). The biological implica- 
tions of these rearrangements in healthy individuals demand further investigation. Nonetheless, their presence does not seem to be predictive of a developing malignancy, but rather they are likely to be indicative of transient genomic instability.

\section{ACKNOWLEDGMENTS}

The author wishes to express her gratitude to Dr. Elvis Terci Valera for carefully reading the manuscript and offering valuable suggestions.

\section{REFERENCES}

Alexander FE, Patheal SL, Biondi A, Brandalise S, et al. (2001). Transplacental chemical exposure and risk of infant leukemia with MLL gene fusion. Cancer Res. 61: 2542-2546.

Andreasson P, Schwaller J, Anastasiadou E, Aster J, et al. (2001). The expression of ETV6/CBFA2 (TEL/AML1) is not sufficient for the transformation of hematopoietic cell lines in vitro or the induction of hematologic disease in vivo. Cancer Genet. Cytogenet. 130: 93-104.

Bäsecke J, Griesinger F, Trumper L and Brittinger G (2002). Leukemia- and lymphoma-associated genetic aberrations in healthy individuals. Ann. Hematol. 81: 64-75.

Bäsecke J, Podleschny M, Clemens R, Schnittger S, et al. (2006). Lifelong persistence of AML associated MLL partial tandem duplications (MLL-PTD) in healthy adults. Leuk. Res. 30: 1091-1096.

Bell DA, Liu Y and Cortopassi GA (1995). Occurrence of bcl-2 oncogene translocation with increased frequency in the peripheral blood of heavy smokers. J. Natl. Cancer Inst. 87: 223-224.

Betti CJ, Villalobos MJ, Diaz MO and Vaughan AT (2003). Apoptotic stimuli initiate MLL-AF9 translocations that are transcribed in cells capable of division. Cancer Res. 63: 1377-1381.

Biernaux C, Loos M, Sels A, Huez G, et al. (1995). Detection of major bcr-abl gene expression at a very low level in blood cells of some healthy individuals. Blood 86: 3118-3122.

Bocchia M, Korontsvit T, Xu Q, Mackinnon S, et al. (1996). Specific human cellular immunity to BCR-ABL oncogenederived peptides. Blood 87: 3587-3592.

Bose S, Deininger M, Gora-Tybor J, Goldman JM, et al. (1998). The presence of typical and atypical BCR-ABL fusion genes in leukocytes of normal individuals: biologic significance and implications for the assessment of minimal residual disease. Blood 92: 3362-3367.

Brassesco MS (2006). Alterações no gene $M L L$ (11q23) em linfócitos de pacientes que receberam tratamento para leucemia linfóide aguda na infância. Rev. Med. 40: 122-123 (Resumos de Teses).

Brassesco MS, Camparoto ML, Tone LG and Sakamoto-Hojo ET (2004). Analysis of ETV6/RUNX1 fusions for evaluating the late effects of cancer therapy in ALL (acute lymphoblastic leukemia) cured patients. Cytogenet. Genome Res. 104: 346-351.

Broeker PL, Super HG, Thirman MJ, Pomykala H, et al. (1996). Distribution of 11q23 breakpoints within the MLL breakpoint cluster region in de novo acute leukemia and in treatment-related acute myeloid leukemia: correlation with scaffold attachment regions and topoisomerase II consensus binding sites. Blood 87: 1912-1922.

Busson-le Coniat M, Poirel H, Leblanc T, Bernard O, et al. (1999). Loss of the TEL/ETV6 gene by a second translocation in ALL patients with $\mathrm{t}(12 ; 21)$. Leukemia Res. 23: 895-899.

Camparoto ML (2005). Efeitos genéticos tardios das terapias anticâncer detectadas pela análise de fusões gênicas em pacientes curados de leucemia e linfoma na infância. Rev. Med. 38: 184-185 (Resumos de Teses).

Coustan-Smith E, Sancho J, Hancock ML, Boyett JM, et al. (2000). Clinical importance of minimal residual disease in childhood acute lymphoblastic leukemia. Blood 96: 2691-2696.

De Vries JH, Hollman PC, Meyboom S, Buysman MN, et al. (1998). Plasma concentrations and urinary excretion of the antioxidant flavonols quercetin and kaempferol as biomarkers for dietary intake. Am. J. Clin. Nutr. 68: 60-65.

Dobson CL, Warren AJ, Pannell R, Forster A, et al. (1999). The mll-AF9 gene fusion in mice controls myeloproliferation and specifies acute myeloid leukaemogenesis. EMBO J. 18: 3564-3574.

Eguchi-Ishimae M, Eguchi M, Ishii E, Miyazaki S, et al. (2001). Breakage and fusion of the TEL (ETV6) gene in immature B lymphocytes induced by apoptogenic signals. Blood 97: 737-743.

Felix CA, Walker AH, Lange BJ, Williams TM, et al. (1998). Association of CYP3A4 genotype with treatment-related leukemia. Proc. Natl. Acad. Sci. U. S. A. 95: 13176-13181. 
Ferguson DO and Alt FW (2001). DNA double strand break repair and chromosomal translocation: lessons from animal models. Oncogene 20: 5572-5579.

Forster A, Pannell R, Drynan LF, McCormack M, et al. (2003). Engineering de novo reciprocal chromosomal translocations associated with MLL to replicate primary events of human cancer. Cancer Cell 3: 449-458.

Franke AA, Custer LJ and Tanaka Y (1998). Isoflavones in human breast milk and other biological fluids. Am. J. Clin. Nutr. 68: 1466S-1473S.

Fukutake M, Takahashi M, Ishida K, Kawamura H, et al. (1996). Quantification of genistein and genistin in soybeans and soybean products. Food Chem. Toxicol. 34: 457-461.

Gale KB, Ford AM, Repp R, Borkhardt A, et al. (1997). Backtraking leukemia to birth: identification of clonotypic gene fusion sequences in neonatal blood spots. PNAS 94: 13950-13954.

Greaves MF (1997). Aetiology of acute leukaemia. Lancet 349: 344-349.

Greaves M (1999). Molecular genetics, natural history and the demise of childhood leukaemia. Eur. J. Cancer 35: 173-185.

Greaves M (2002). Childhood leukaemia. BMJ 324: 283-287.

Greaves MF and Wiemels J (2003). Origins of chromosome translocations in childhood leukaemia. Nat. Rev. Cancer 3: 639-649.

Hanahan D and Weinberg RA (2000). The hallmarks of cancer. Cell 100: 57-70.

Hattori M, Tanaka M, Yamazaki Y, Nakahara Y, et al. (1995). Detection of major and minor bcr/abl fusion gene transcripts in a patient with acute undifferentiated leukemia secondary to treatment with an alkylating agent. Leuk. Res. 19: 389-396.

Hensel JP, Gillert E, Fey GH and Marschalek R (2001). Breakpoints of t(4;11) translocations in the human MLL and AF4 genes in ALL patients are preferentially clustered outside of high-affinity matrix attachment regions. J. Cell Biochem. 82: 299-309.

Hertog MG, Feskens EJ, Hollman PC, Katan MB, et al. (1994). Dietary flavonoids and cancer risk in the Zutphen Elderly Study. Nutr. Cancer 22: 175-184.

Hiebert SW, Sun W, Davis JN, Golub T, et al. (1996). The t(12;21) translocation converts AML-1B from an activator to a repressor of transcription. Mol. Cell Biol. 16: 1349-1355.

Hollman PC, van Trijp JM, Mengelers MJ, De Vries JH, et al. (1997). Bioavailability of the dietary antioxidant flavonol quercetin in man. Cancer Lett. 114: 139-140.

Hunger SP and Cleary ML (1998). What significance should we attribute to the detection of MLL fusion transcripts? Blood 92: 709-711.

Kempski HM and Sturt NT (2000). The TEL-AML1 fusion accompanied by loss of the untranslocated TEL allele in B-precursor acute lymphoblastic leukaemia of childhood. Leuk. Lymphoma 40: 39-47.

Kim-Rouille MH, MacGregor A, Wiedemann LM, Greaves MF, et al. (1999). MLL-AF4 gene fusions in normal newborns. Blood 93: 1107-1108.

Lavau C, Szilvassy SJ, Slany R and Cleary ML (1997). Immortalization and leukemic transformation of a myelomonocytic precursor by retrovirally transduced HRX-ENL. EMBO J. 16: 4226-4237.

Lipkowitz S, Garry VF and Kirsch IR (1992). Interlocus V-J recombination measures genomic instability in agriculture workers at risk for lymphoid malignancies. Proc. Natl. Acad. Sci. U. S. A. 89: 5301-5305.

Liu Y, Hernandez AM, Shibata D and Cortopassi GA (1994). BCL2 translocation frequency rises with age in humans. Proc. Natl. Acad. Sci. U. S. A. 91: 8910-8914.

Loh ML, Silverman LB, Young ML, Neuberg D, et al. (1998). Incidence of TEL/AML1 fusion in children with relapsed acute lymphoblastic leukemia. Blood 92: 4792-4797.

Ma X, Buffler PA, Gunier RB, Dahl G, et al. (2002). Critical windows of exposure to household pesticides and risk of childhood leukemia. Environ. Health Perspect. 110: 955-960.

Marculescu R, Le T, Simon P, Jaeger U, et al. (2002). V(D)J-mediated translocations in lymphoid neoplasms: a functional assessment of genomic instability by cryptic sites. J. Exp. Med. 195: 85-98.

Megonigal MD, Cheung NK, Rappaport EF, Nowell PC, et al. (2000). Detection of leukemia-associated MLL-GAS7 translocation early during chemotherapy with DNA topoisomerase II inhibitors. Proc. Natl. Acad. Sci. U. S. A. 97: 2814-2819.

Mori H, Colman SM, Xiao Z, Ford AM, et al. (2002). Chromosome translocations and covert leukemic clones are generated during normal fetal development. Proc. Natl. Acad. Sci. U. S. A. 99: 8242-8247.

Nakamura $\mathrm{N}$ (2005). A hypothesis: radiation-related leukemia is mainly attributable to the small number of people who carry pre-existing clonally expanded preleukemic cells. Radiat. Res. 163: 258-265.

Nakamura Y, Tsuji S and Tonogai Y (2000). Determination of the levels of isoflavonoids in soybeans and soy-derived foods and estimation of isoflavonoids in the Japanese daily intake. J. AOAC Int. 83: 635-650.

Pinilla-Ibarz J, Cathcart K, Korontsvit T, Soignet S, et al. (2000). Vaccination of patients with chronic myelogenous 
leukemia with BCR-ABL oncogene breakpoint fusion peptides generates specific immune responses. Blood 95: 1781-1787.

Prior RL (2003). Fruits and vegetables in the prevention of cellular oxidative damage. Am. J. Clin. Nutr. 78: 570S-578S.

Quina AS, Gameiro P, Sa da Costa, Telhada M, et al. (2000). PML-RARA fusion transcripts in irradiated and normal hematopoietic cells. Genes Chromosomes Cancer 29: 266-275.

Rauzy O, Galoin S, Chale JJ, Adoue D, et al. (1998). Detection of t(14;18) carrying cells in bone marrow and peripheral blood from patients affected by non-lymphoid diseases. Mol. Pathol. 51: 333-338.

Ross JA (2000). Dietary flavonoids and the MLL gene: A pathway to infant leukemia? Proc. Natl. Acad. Sci. U. S. A. 97 : 4411-4413.

Roulston D, Espinosa R III, Nucifora G, Larson RA, et al. (1998). CBFA2(AML1) translocations with novel partner chromosomes in myeloid leukemias: association with prior therapy. Blood 92: 2879-2885.

Rowley JD (1999). The role of chromosome translocations in leukemogenesis. Semin. Hematol. 36: 59-72.

Schnittger S, Wormann B, Hiddemann W and Griesinger F (1998). Partial tandem duplications of the MLL gene are detectable in peripheral blood and bone marrow of nearly all healthy donors. Blood 92: 1728-1734.

Schüz J, Kaletsch U, Meinert R, Kaatsch P, et al. (2000). Risk of childhood leukemia and parental self-reported occupational exposure to chemicals, dusts, and fumes: results from pooled analyses of German population-based case-control studies. Cancer Epidemiol. Biomarkers Prev. 9: 835-838.

Seedhouse C, Faulkner R, Ashraf N, Das-Gupta E, et al. (2004). Polymorphisms in genes involved in homologous recombination repair interact to increase the risk of developing acute myeloid leukemia. Clin. Cancer Res. 10: 26752680.

Seeger H, Dams H, Buchwald D, Beyermann B, et al. (1998). TEL-AML1 fusion transcript in relapsed childhood acute lymphoblastic leukemia. Blood 91: 1716-1722.

Shu XO, Ross JA, Pendergrass TW, Reaman GH, et al. (1996). Parental alcohol consumption, cigarette smoking, and risk of infant leukemia: a Children's Cancer Group study. J. Natl. Cancer Inst. 88: 24-31.

Shu XO, Stewart P, Wen WQ, Han D, et al. (1999). Parental occupational exposure to hydrocarbons and risk of acute lymphocytic leukemia in offspring. Cancer Epidemiol. Biomarkers Prev. 8: 783-791.

Stanulla M, Wang J, Chervinsky DS, Thandla S, et al. (1997). DNA cleavage within the MLL breakpoint cluster region is a specific event which occurs as part of higher-order chromatin fragmentation during the initial stages of apoptosis. Mol. Cell Biol. 17: 4070-4079.

Strick R, Strissel PL, Borgers S, Smith SL, et al. (2000). Dietary bioflavonoids induce cleavage in the MLL gene and may contribute to infant leukemia. Proc. Natl. Acad. Sci. U. S. A. 97: 4790-4795.

Strick R, Zhang Y, Emmanuel N and Strissel PL (2006). Common chromatin structures at breakpoint cluster regions may lead to chromosomal translocations found in chronic and acute leukemias. Hum. Genet. 119: 479-495.

Strissel PL, Strick R, Rowley JD and Zeleznik-Le NJ (1998). An in vivo topoisomerase II cleavage site and a DNase I hypersensitive site colocalize near exon 9 in the MLL breakpoint cluster region. Blood 92: 3793-3803.

Strissel PL, Strick R, Tomek RJ, Roe BA, et al. (2000). DNA structural properties of AF9 are similar to MLL and could act as recombination hot spots resulting in MLL/AF9 translocations and leukemogenesis. Hum. Mol. Genet. 9: 1671-1679.

Strout MP, Marcucci G, Bloomfield CD and Caligiuri MA (1998). The partial tandem duplication of ALL1 (MLL) is consistently generated by Alu-mediated homologous recombination in acute myeloid leukemia. Proc. Natl. Acad. Sci. U. S. A. 95: 2390-2395.

Summers KE, Goff LK, Wilson AG, Gupta RK, et al. (2001). Frequency of the Bcl-2/IgH rearrangement in normal individuals: implications for the monitoring of disease in patients with follicular lymphoma. J. Clin. Oncol. 19: 420-424.

Trka J, Zuna J, Hrusak O, Michalova K, et al. (1999). No evidence for MLL/AF4 expression in normal cord blood samples. Blood 93: 1106-1107.

Tucker JD and Preston RJ (1996). Chromosome aberrations, micronuclei, aneuploidy, sister chromatid exchanges, and cancer risk assessment. Mutat. Res. 365: 147-159.

Uckum FM, Herman-Haten K, Crotty ML, Sensel MG, et al. (1998). Clinical significance of MLL-AF4 fusion transcript expression in the absence of a cytogenetically detectable $\mathrm{t}(4 ; 11)(\mathrm{q} 21 ; \mathrm{q} 23)$ chromosomal translocation. Blood 92 : 810-821.

Vaughan AT, Betti CJ, Villalobos MJ, Premkumar K, et al. (2005). Surviving apoptosis: a possible mechanism of benzeneinduced leukemia. Chem. Biol. Interact. 153-154: 179-185.

Vega F and Medeiros LJ (2003). Chromosomal translocations involved in non-Hodgkin lymphomas. Arch. Pathol. Lab. Med. 127: 1148-1160.

Watanabe S, Yamaguchi M, Sobue T, Takahashi T, et al. (1998). Pharmacokinetics of soybean isoflavones in plasma, 
urine and feces of men after ingestion of $60 \mathrm{~g}$ baked soybean powder (kinako). J. Nutr. 128: 1710-1715.

Whitman SP, Strout MP, Marcucci G, Freud AG, et al. (2001). The partial nontandem duplication of the MLL (ALL1) gene is a novel rearrangement that generates three distinct fusion transcripts in B-cell acute lymphoblastic leukemia. Cancer Res. 61: 59-63.

Wiemels JL, Ford AM, Van Wering ER, Postma A, et al. (1999a). Protracted and variable latency of acute lymphoblastic leukemia after TEL-AML1 gene fusion in utero. Blood 94: 1057-1062.

Wiemels JL, Pagnamenta A, Taylor GM, Eden OB, et al. (1999b). A lack of a functional NAD(P)H:quinone oxidoreductase allele is selectively associated with pediatric leukemias that have MLL fusions. United Kingdom Childhood Cancer Study Investigators. Cancer Res. 59: 4095-4099.

Yasukawa M, Bando S, Dolken G, Sada E, et al. (2001). Low frequency of BCL-2/J(H) translocation in peripheral blood lymphocytes of healthy Japanese individuals. Blood 98: 486-488.

Yotnda P, Firat H, Garcia-Pons F, Garcia Z, et al. (1998a). Cytotoxic T cell response against the chimeric p210 BCR-ABL protein in patients with chronic myelogenous leukemia. J. Clin. Invest. 101: 2290-2296.

Yotnda P, Garcia F, Peuchmaur M, Grandchamp B, et al. (1998b). Cytotoxic T cell response against the chimeric ETV6AML1 protein in childhood acute lymphoblastic leukemia. J. Clin. Invest. 102: 455-462. 